\title{
INFLUENCE DE LA MICROFLORE INTESTINALE SUR CERTAINS ASPECTS DU MÉTABOLISME DES ACIDES BILIAIRES CHEZ LE RAT
}

\author{
H. GARNIER et E. SACQUET \\ Service des Animaux sans Germes, C. N.R. S.. \\ Groupe des Laboratoires, \\ 91 - Gif-sur-Yvette
}

La bile du rat axénique contient 2,4 fois plus d'acide cholique et 3 fois plus d'acides biliaires totaux que la bile du rat holoxénique. D'autre part, le pourcentage d'acide cholique conjugué a la taurine est légèrement plus important chez le rat axénique que chez le rat holoxénique (respectivement 99 p. 100 et 97,4 p. I00).

Comparée à la bile de l'holoxénique, la bile de l'axénique contient davantage d'acide $\beta$-muricholique, moins d'acide cholique et la répartition des acides biliaires dihydroxylés est différente.

Comme la bile, l'intestin grêle du rat axénique contient trois fois plus d'acides biliaires totaux que l'intestin grêle du rat holoxénique. Dans les deux cas, des différences apparaissent entre la composition en acides biliaires au niveau de l'intestin grêle et la composition au niveau de la bile.

La formation d'une anse aveugle au niveau du jéjunum induit une augmentation de l'excrétion fécale des graisses chez le rat holoxénique et chez les rats gnotoxéniques utilisés. Au niveau de l'intestin" grêle, on observe une diminution de la quantité d'acides biliaires conjugués chez le rat holoxénique et chez le rat gnotoxénique porteurs d'une anse, par rapport à l'holoxénique non opéré. Chez les rats gnotoxéniques utilisés, il n'y a pas d'acide déoxycholique : la présence d'acide déoxycholique n'est donc pas nécessaire à l'apparition de la stéatorrhée.

Quarante-huit heures après interruption du cycle entéro-hépatique, la bile du rat axénique et la bile du rat holoxénique arrivent à des compositions en acides biliaires très voisines : mêmes quantités relatives d'acide cholique et d'acide $\beta$-muricholique. Dans les deux cas l'acide cholique est plus abondant que l'acide $\beta$-muricholique. Chez le rat holoxénique, on observe déjà à ce moment une disparition presque totale des métabolites bactériens des acides biliaires.

\section{SUMMARY}

\section{INFLUENCE OF THE INTESTINAL, MICROFLORA UPON BILE ACIDS ME'TABOL,ISM IN THE RAT}

In the axenic rat, bile contains 2.4 times more cholic acid and 3 times more total bile acids than in the holoxenic (1) rat. The percentage of cholic acid conjugated with taurine is slightly higher in the axenic rat than in the holoxenic rat (respectively 99 p. Ioo vs 97.4 p. I00).

Compared with the bile of the holoxenic rat, the bile of the axenic rat contains more $\beta$-muricholic acid, less cholic acid and the composition of the dihydroxylated bile acids is different.

The small intestine of the axenic rat contains 3 times more total bile acids than the small

(1) Holoxenic : conventional. 
intestine of the holoxenic rat. In each group of rats, the bile acid composition observed in the small intestine and in the bile is different.

When holoxenic and gnotoxenic rats were provided with a jejunal self-filling blind loop, an increase in the faecal excretion of fat took place together with a decrease in the amount of conjugated bile acids at the level of small intestine. Deoxycholic acid was not observed in the gnotoxenic rat : therefore, presence of deoxycholic acid does not appear to be necessary to the development of steatorrhea in the blind loop syndrome.

Forty-eight hours after interruption of the entero-hepatic cycle, the biliary bile acid composition in the axenic rats and in the holoxenic rats were found to be similar : particularly, similar relative amounts of cholic acid and $\beta$-muricholic acid were observed in both groups. As a result, in the bile of the axenic rat, the amount of cholic acid was higher than that of $\beta$-muricholic acid. In the holoxenic rats, a nearly total disappearance of the bacterial metabolites of bile acids had already taken place.

\title{
LES MATIËRES AZOTÉES DES CONTENUS DE CAECUM DE RAT: MÉTHODE D'ÉTUDE ET RÉSULTATS OBTENUS : INFLUENCE DE L'ÉTAT AXÉNIQUE
}

\author{
R. PION, C. VALENZA et E. COMBE \\ Station d'Études des Métabolismes, \\ Centra de Recherches de Clermont-Ferrand, I. N.R. A., \\ 63 - Saint-Genès-Champanelle
}

En vue d'étudier la composition des matières azotées des contenus de cæcums des rats axéniques et holoxéniques, nous les avions dans un premier temps divisées en trois fractions : les composés solubles dans l'éthanol 82 p. roo, les composés insolubles dans l'éthanol et solubles dans l'acide trichloracétique à ıo p. soo (ATC), et le résidu insoluble dans ces deux solvants. Nous avons pu ainsi mettre en évidence certaines différences dans la répartition de l'azote entre ces fractions et leurs compositions en acides aminés chez les animaux axéniques et holoxéniques, ainsi que la liaison entre la composition des contenus de cæcums des rats axéniques et la nature et le taux protéique de la ration ingérée. Nous avons cherché à améliorer la technique de fractionnement, en effectuant préalablement à l'extraction par l'éthanol une solubilisation d'une partie des composés présents dans le chlorure de sodium 9 p. rooo, suivie d'une centrifugation (3o ooo $g$ ). Nous avons déterminé par chromatographie sur colonne au moyen d'un appareil automatique les compositions en acides aminés totaux des différentes fractions, ainsi que les compositions en acides aminés libres des extraits. Nous avons utilisé, pour l'estimation de la taille des molécules peptidiques présentes des séparations sur gel de "Sephadex » et sur "Biogel $P$ » ainsi que le dosage des groupements aminés libres.

Les extraits éthanoliques renferment la majorité des acides aminés libres et amides, associés à des peptides ; les extraits par l'ATC contiennent une proportion appréciable de certains acides aminés libres (acide aspartique, alanine, sérine et glutamine en particulier), des peptides et dans le cas des animaux axéniques, des protéines. Les contenus de cæcum des animaux axéniques 